\title{
PEMBERIAN VCO (VIRGIN COCONUT OIL) PADA Tn. M DENGAN DIAGNOSIS MEDIS CVA INFARK DENGAN MASALAH KEPERAWATAN RISIKO KERUSAKAN INTEGRITAS KULIT DI RUANG ICU CENTRAL RUMKITAL dr. RAMELAN SURABAYA
}

\author{
Eppy Setiyowati \\ Fakultas Kedokteran Universitas Nahdlatul Ulama Surabaya \\ e-mail: eppy@unusa.ac.id
}

\begin{abstract}
Abstrak: Ulkus dekubitus merupakan masalah dermatologi yang sangat serius terutama pasien yang dirawat di ICU, pasien tidak sadar, dan kurang mobilisasi. Ukus dekubitus terjadi pada area yang terlokalisir dengan jaringan yang mengalami nekrosis dan biasanya terjadi pada permukaan tulang yang menonjol, sebagai akibat dari tekanan dalam jangka waktu yang lama menyebabkan peningkatan tekanan kapiler. Penelitian ini bertujuan untuk mengetahui seberapa besar efektivitas penerapan pemberian VCO pada pasien yang berisiko terkena ulkus dekubitus di ruang ICU Central RSAL dr. Ramelan Surabaya. Rancangan penelitian yang digunakan adalah studi kasus. Penelitian studi kasus dilakukan dengan cara meneliti permasalahan melalui satu kasus yang terdiri dari unit tunggal. Variabel yang digunakan adalah pemberian minyak kelapa murni VCO pada pasien yang berisiko terkena ulkus dekubitus. Teknik analisis data yang digunakan adalah deskriptif. Cara analisis dengan pendekatan analisis induktif. Berdasarkan hasil studi kasus di atas dapat ditarik kesimpulan yaitu pemberian VCO pada pasien Tn. M dengan masalah keperawatan risiko kerusakan integritas kulit menghasilkan ada pengaruh dalam pemberian VCO untuk mencegah terjadinya dekubitus.
\end{abstract}

Kata Kunci: dekubitus, VCO (virgin coconut oil)

\begin{abstract}
Ulcus decubitus is a serious dermal (skin) problem, especially for the unconscious patients with the lack of mobilization hospitalized in the ICU. It appears in the area which is localized with the necrotic tissues; it also usually appears on the surface of protruding bones, resulted from the long term pressure which increases the capillary pressure. This study was purposed to analyze the effectiveness of the use of VCO to the patient with the risk of having ulcus decubitus in the central ICU of Rumkital Dr. Ramelan Surabaya (Surabaya Navy Hospital). The design used in this study was case study done by investigating a problem through one case comprising of a single unit. The variable used in this study was the use of VCO to the patient with the risk of ulcus decubitus. The data were analyzed descriptively done by using inductive approach. The result of this study concludes that the use of VCO to Mr. M who has the risk of impaired skin integrity is effective to prevent decubitus.
\end{abstract}

Keywords: decubitus, VCO (virgin coconut oil)

\section{PENDAHULUAN}

CVA (Cerebro Vascular Accident) adalah defisit neurologis yang mempunyai awitan tibatiba, berlangsung lebih dari 24 jam, dan disebabkan oleh penyakit serebrovascular (Ida, 2010). CVA terjadi pada saat terdapat gangguan aliran darah ke bagian otak. Aliran darah terganggu karena adanya sumbatan pembuluh darah, karena trombus atau embolus, atau ruptur pembuluh darah (Morton et al., 2012). Seseorang yang menderita CVA tidak dapat melakukan aktivitas seperti biasanya sehingga penderita mengalami penurunan mobilitas fisik dan dirawat di tempat tidur (bedrest). Bedrest yang lama tanpa adanya 
perubahan posisi atau miring kanan dan miring kiri dapat menimbulkan adanya luka tekan. Menurut suatu penelitian di Indonesia yang dilakukan oleh Suriadi (2007) angka kejadian luka dekubitus mencapai 33,3\%. Dan tidak terjadi penurunan angka kejadian dekubitus. Kejadian dekubitus cukup bervariasi, tapi secara umum dilaporkan bahwa $5-11 \%$ terjadi tatanan perawatan jangka panjang dan 7-12\% di tatanan perawatan atau home care.

Di Dr. Soetomo Surabaya adalah Rumah sakit tipe A atau sebagai Rumah Sakit rujukan utama di Indonesia Timur.Hasil survei Praktika Senior pada tanggal 5 Mei 2016 di ruang ICU Central RUMKITAL DR. Ramelan Surabaya, didapatkan data bahwa terdapat 3 kasus Ulkus dekubitus selama 1 bulan terakhir. Marison (2003) dalam jurnal keperawatan HKBP balige (2013) mengatakan ulkus dekubitus merupakan ancaman yang sangat besar bagi populasi pasien yang dirawat di rumah sakit maupun perawatan lainnya.

Di ruang ICU Central RS Dr. Ramelan Surabaya penanganan pasien yang terkena ulkus dekubitus hanya menggunakan handbody dan miring kanan dan kiri. (Price, 2006) menyatakan jika menggunakan lotion biasa untuk perawatan kulit, umumnya lotion menggunakan komponen air sehingga ketika dipakai akan memberikan kesegaran sesaat namun kandungan airnya hilang karena penguapan, sehingga berisiko terjadinya ulkus dekubitus. Sedangkan minyak kelapa murni unsur oksidan dan vitamin $\mathrm{E}$ masih bisa dipertahankan dan sebaliknya pada minyak goreng biasa, sehingga bila digunakan untuk perawatan kulit minyak goreng biasa akan menciptakan radikal bebas di permukaan kulit dan menyebabkan kerusakan jaringan. Jika dipakai secara topikal atau dipakai ke dalam, minyak kelapa membantu kulit tetap muda, sehat dan bebas dari penyakit. Asam lemak antiseptik pada minyak kelapa membantu mencegah infeksi jamur dan bakteri jika ditambahkan dalam diet atau dipakaikan langsung pada kulit. Sehingga minyak kelapa murni dapat digunakan untuk mencegah terjadinya luka tekan atau ulkus dekubitus. Menurut hasil penelitian dari (Diah Setiani 2014) ada pengaruh perawatan kulit perawatan kulit dengan pemberian VCO untuk pencegahan kejadian luka tekan pasien yang dirawat di ICU, ada perbedaan kejadian luka tekan antara kelompok intervensi dan kelompok dalam rentang nilai yang sama. Hal ini ditunjukkan pada hasil statistik deskriptif bahwa pada kelompok pembekuan yaitu kelompok yang mendapatkan massage dengan VCO tidak terjadi luka tekan, sedangkan pada kelompok kontrol atau kelompok yang mendapatkan perawatan standar ruangan, terjadi luka tekan. Menurut hasil penelitian (Betty Sunaryanti 2012) ada pengaruh dalam pemberian VCO terhadap pencegahan ulkus dekubitus pada responden yang diberikan VCO, sedangkan responden yang tidak diberikan VCO terjadi tanda ulkus dekubitus.

Berdasarkan latar belakang tersebut, maka penulis tertarik untuk melakukan pengelolaan kasus asuhan keperawatan yang akan dituangkan dalam bentuk karya tulis ilmiah dengan judul "Pemberian VCO (Virgin Coconut Oil) pada Pasien Tn. M dengan Diagnosa Medis CVA Infark Dengan Masalah Keperawatan Risiko Kerusakan Integritas Kulit di Ruang ICU Central RUMKITAL Dr. Ramlan Surabaya”.

\section{HASIL PENELITIAN}

Hasil dari inovasi yang dilakukan kemungkinan tingkat kegagalan yang terjadi sangat kecil dikarenakan dalam proses pemberian VCO peneliti selalu memperhatikan tingkat kelembaban 
kulit, posisi yang terkena ulkus dekubitus, kebersihan pasien dan juga tempat tidur, tujuannya untuk meminimalisasi timbulnya infeksi yang disebabkan oleh bakteri.

Sebelum pasien diberikan VCO pertama Kulit dibersihkan pada saat kotor dan atau secara rutin. Frekuensi membersihkan tergantung kebutuhan pasien. Menggunakan sabun lembut dan digosokkan secara pelan-pelan dengan kuat pada kulit, baru dioleskan VCO ke seluruh tubuh secara merata terutama di bagian yang terkena ulkus dekubitus. Untuk proses penyembuhan yang lebih optimal peneliti memberikan minyak sebanyak 2 kali per hari pagi dan sore, setelah di olesi VCO juga di lakukan tindakan miring kanan dan kiri.

Upaya pencegahan luka tekan dinyatakan dalam beberapa literatur $(\mathrm{MOH} 2001$, EPUAP \& NPUAP 2009, NGC 2008, Mukti 1998) yang merujuk kepada beberapa hasil penelitian dan evidence secara garis besar terdiri dari upayaupaya.

Penggunaan secara topikal langsung pada kulit diyakini sebagai cara terbaik untuk mendapatkan manfaat VCO. Cara ini akan mengembalikan elastisitas kulit dengan cepat dan efektif (Coconut-oil- central. n.d ). Trevtick \& Miton (1999) dalam penelitiannya menyimpulkan Vitamin E dari VCO yang diberikan secara topikal dapat terserap dalam 24 jam. Wang dan Quinn (1999) menyatakan vitamin $\mathrm{E}$ adalah zat yang berfungsi sebagai stabilizer membrane sel, melindungi kerusakan sel dari radikal bebas dan sebagai simpanan lemak dalam organel sel. Selain itu VCO mempunyai kemampuan antioksidan, antimikrobial, anti-fungi, melindungi kulit dari bahaya radikal bebas degenerasi jaringan ( $\mathrm{Co}-$ conut Research Center, 2004).

\section{PEMBAHASAN}

Pemberian minyak kelapa murni VCO secara rutin dan continue diberikan pada area yang terkena luka tekan Grade I. Kandungan asam lemak (terutama asam laurat dan oleat) bersifat melembutkan kulit dan antimicrobial sehingga VCO efektif dan aman digunakan sebagai moisturizer pada kulit (Agero and-Rowell, 2008; Lucida, Salman \& Hervian, 2012).

Dalam hal ini peneliti melakukan suatu inovasi yang dilakukan pada Tn.M dengan menerapkan tindakan keperawatan tentang pemberian minyak kelapa murni VCO sesuai dengan teori dan jurnal yang ada. Penggunaan minyak VCO yang diolesi ke kulit pasien yang memerah secara teratur dan continue. Pemberian minyak kelapa murni VCO yang dilakukan peneliti pada pasien Tn.M dilaksanakan selama 3 hari berturut-turut dari tanggal 11-13 Mei 2016. Pemberian VCO dilakukan setiap 2 kali sehari. Pemberian VCO yang peneliti lakukan adalah sesuai dengan jadwal shift di mana peneliti berdinas. Sedangkan pada saat peneliti tidak berdinas tugas tersebut dilanjutkan oleh mahasiswa yang praktik keperawatan di ruang ICU. Pada saat melakukan pemberian VCO pada pasien peneliti tidak menemukan kendala.

\section{KESIMPULAN DAN SARAN}

\section{Simpulan}

Berdasarkan hasil studi kasus di atas dapat ditarik kesimpulan yaitu penerapan pemberian minyak kelapa murni VCO pada pasien Tn. M dengan tirah baring lama menghasilkan dekubitus Grade I tidak terjadi dan gejala kemerahan yang ditimbulkan oleh luka tekan dekubitus Grade I hilang. 


\section{Saran}

1. Bagi perawat dan tenaga medis

Perawat pelaksana dapat menerapkan teknik pemberian minyak kelapa murni VCO pada seluruh pasien tirah baring lama, sehingga terjadinya dekubitus dapat diminimalisasi.

2. Bagi institusi pendidikan penerapan teknik pemberian minyak kelapa murni VCO dapat dimasukkan dalam proses pembelajaran dan dapat dilakukan dengan memberikan materi‘.

\section{DAFTAR PUSTAKA}

Amin, Sarmidi. 2009. Cocopreneurship Aneka Peluang Bisnis dari Kelapa. Yogyakarta: Lily Publisher.

Ariani, T.A. 2012. Sistem Neurobehaviour. Edisi Pertama. Jakarta: Salemba Medika.

Corwin, E.J. 2009. Buku Saku Patofisiologi. Jakarta: EGC.

Dermawan, D. 2012. Proses Keperawatan Penerapan Konsep \& Kerangka Kerja. Edisi Pertama. Yogyakarta: Gosyen Publishing.

Muttaqin, A. 2008. Buku Ajar Asuhan Keperawatan Klien dengan Gangguan Sistem Persarafan. Edisi Pertama. Jakarta: Salemba Medika.

M. Bulechek, et al. 2013. Nursing Intervention Classification (NIC) Sixth Edition. MOSBY.
Mariana, Bella dkk. 2013. Pencegahan Kejadian Luka Tekan Melalui Massage Virgin Coconut Oil pada Pasien dengan Imobilisasi, 1(1): 38-42.

NANDA. 2011. Diagnosa Keperawatan Definisi dan Klasifikasi 2012-2014. Jakarta: EGC.

Price, Murai. 2003. Terapi Minyak Kelapa (Bahrul Ulum, Penerjemah). 2004. Jakarta: Prestasi Pustaka Publisher.

Potter, P.A. \& Perry, A.G. 2007. Basic Nursing Skill Essential for Practice. Canada: Mosby Elsevier.

Sabandar, O.A. 2008. Decubitus. January 31, 2010.

Siswono. 2006. Manfaat Minyak Kelapa Murni (VCO) untuk Kesehatan. Diakses dari http://www.republika.co.id.

Sunaryanti, Betty dkk. 2013. Perubahan Pengaruh antara Pemberian Minyak Kelapa dan Madu

Widodo, A. 2007. Uji Kepekaan Instrumen Pengkajian Risiko Dekubitus dalam Mendeteksi Dini Risiko Kejadian Dekubitus di RSIS. Surakarta: Universitas Muhamadiyah. A. Widodo-2007-publikasiilmiah.ums.ac.id. 15 Juni 2016 (09:36).

Wilkinson, J.M. 2007. Buku Saku Diagnosa Keperawatan dengan Intervensi NIC dan Kriteria Hasil NOC. Edisi ketujuh. Jakarta: EGC. 